\title{
Vulgar geographies? Popular cultural geographies and technology
}

Samuel Kinsley*

Geography, College of Life and Environmental Sciences, University of Exeter, Amory Building, Rennes Drive, Exeter, Devon, EX4 4RJ, United Kingdom

(Accepted 18 December 2015)

In concluding Maps of Meaning Peter Jackson offers a provocation that continues to resonate in contemporary debates around cultural geography, such as affect and emotion, identity and difference or the human and non-human:

If cultural geography is to be revitalised, ... 'It can only be by an engagement with the contemporary intellectual terrain - not to counter a threat, but to discover an opportunity' (Jackson 1989: 180; Stedman Jones 1983: 24).

To explore what opportunities contemporary cultural phenomena may present for geographers, this short article poses two related questions: the first question is where is 'popular culture' in cultural geography? Following from this, and by way of arguing that contemporary popular culture is always mediated, the second question is how do we address the technologies of (popular) culture in our geographies?

The first part of this provocation, then, is: should cultural geography be more vulgar? The choice of words is deliberately provocative, but can be phrased differently as: how might we better accommodate 'popular culture' in our cultural geographies? My intention here is not to imply a derisory quality, I recognise the implication of 'disgust' and 'distaste' in the word 'vulgar', but that might be a perceived connotation of the continued and conspicuous paucity of geographical engagement with 'popular culture'. Thus, on the contrary, in this article I want to challenge such implications. I argue 'vuglar' is therefore a useful (if challenging) means of addressing the place of the 'popular' in cultural geographies. I also recognise that others have alluded to the absence of 'popular' cultural geographies (see: Barnett 2008; Jackson 1989; 2010) and yet, here we are still with a relative paucity of work in geography on 'low', 'mainstream', 'popular', or 'vernacular' cultural geography. 
What then, might it mean to (in some cases: continue to) do 'popular' cultural geography? One might argue — with Rose (2015) — that the first twenty-something years of 'new' cultural geography are founded on readings: reading various landscapes and other spatial formations as texts - as the Duncan's and others asked of us in the late 1980s (for example: Cosgrove and Daniels 1988; Duncan and Duncan 1988). This, of course, speaks to a particular understanding of the medium and the expression of culture: a deliberative cogitation on particular constellations of meaning (of more-or-less stable 'objects'). One might argue that this implicitly goes hand-inhand with a particular aesthetics of literature: when asked to 'read' landscapes it is analogous to reading Charles Dickens or Milan Kundera, and not Dan Brown or EL James. We apparently ought to aspire to an 'unbearable lightness' and not 'fifty shades' of cultural geography.

This sense of aesthetics points us towards another meaning of the 'popular': ordinariness, or the general acceptance of something. Both Barnett $(1998 ; 2008)$ and Jackson (1989) noted (in different senses) the influence of 'cultural studies' in the theoretical influences of the 'cultural turn'. The influence of a related interest (within Cultural Studies) in the ordinariness of popular culture is perhaps less marked (although the 'vernacular' might be a way of addressing this: Revill 2005). Here, again, 'popular' cultural geographers can also make a contribution. Following the example of cultural anthropologists Daniel Miller and Sophie Woodward (2012) we should continue to (perhaps more forcefully) question how 'popular'-cultural geographies, in their 'ordinariness', relate to the normative - the sense in which "the expectation that actions within a social field are likely to be judged as right or wrong, appropriate or inappropriate, proper or transgressive" (Miller and Woodward 2012: 124). We, cultural geographers, are implicated in such normative judgements, and, while I am not suggesting geography is a refuge for Leavisite prejudice, we imply a form of taste concerning what is worthy of study by what we do not write about just as much as that which we do.

While there is a growing body of work that addresses diverse cultural formsfrom electronic dance music (Fraser 2012) to zombie films (May 2010) and videogames (Ash 2009; 2012b) — it is necessary for cultural geographers to combat being (unfairly) seen as what Featherstone (1991) calls 'new cultural intermediaries', which Edensor (2002: 15) describes as 'a contemporary fraction of the middle class who possess knowledge of pop music, film and other manifestations of popular 
culture, and claim status on the basis of this expertise'. Indeed, if we want to tackle such a cultural politics we ought to perhaps recognise that such a 'politics' is a form of what Ranciere (2011) calls a 'redistribution of the sensible'-a reworking of who does the 'reading', and of what - and not simply 'a history of voices from below against one of discourses from above' (Ranciere 2011: 13) but a way of questioning 'the very functioning of these pairs as opposites' (ibid), a way of unsettling the 'basis of expertise'.

I suggest that, to attend to the everyday and to the popular, different media and forms of expression of culture can broaden the suitable analogies available to cultural geography. Indeed, if the 'cultural turn' of the 1980s owed an intellectual debt to forms of literary theory, then we may ask what the range of subsequent theoretical inventions and influences within cultural geography bring to our ways of knowing. What does it mean to think in terms of video, audio, the smart phone and the tablet? So, perhaps a range of different sensibilities of watching, listening or touching, and, dare one even say, counting (or, rather, computing) needs to be added to reading. Such sensibilities might be more accommodating to recent proposals of 'atmospheres' in addition to 'landscapes' of meaning and sensation. For example, we might consider recent work by a number of geographers that has been described as postphenomenological (Ash and Simpson 2014). We are also likely to have to question the different kinds of 'data' we may need to explore and the techniques of analysis for doing so, which may challenge previously comfortable separations of the 'quantitative' and 'qualitative' (for example Kitchin 2014; Rose 2015; Simpson 2011).

This leads to my second question: how do we address the technologies of (popular) culture in our geographies? In extending our epistemological sensibilities, the rise of networked technologies as intimate mediators of geographical experience raises questions about how to articulate the broadening forms of mediation that play a part of spatial experience (for example Ash 2012a; Craine 2007; Kitchin and Dodge 2011; Longhurst 2009). Our techniques for thinking can thus be tied to the mediums through which we express thought. So, to pursue the metaphor, as ever-more 'multimedia' scholars we are, with an increasing intensity, challenged supplement the reading of landscapes as text with the watching of, listening to and touching forms of spatial experience composed as, in and through image, sound and haptics.

To propose a broadening of epistemological techniques for interrogating the world, from 'reading' to 'listening', 'touching' and so on, invites questions about 
'what' is the focus of such techniques: what are the 'objects' of such performances of cultural geography (following Rose 2015)? The important corollary is that such techniques and their objects also ask questions about who is doing the 'reading', 'listening' and 'touching'. As Barnett (2015) has argued (fittingly, in a blogpost) we, cultural geographers, are challenged to reconsider what one might call 'ontology of media'. Of course, and as Barnett (2015) goes on to suggest, there is a danger here that, in our 'reading', 'listening', 'touching' and so on, we make all sorts of assumptions about the discreteness and/or stability of the 'objects' of our attention. In studying popular culture, especially its obviously mediated aspects (such as social media etc.) we simply cannot ignore their technological basis nor assume that media are in some way epistemologically or ontologically neutral. Thus, the ways in which we pay attention to mediation, and its technologies, have the power to elucidate the kinds of sociotechnical investment in culture. There is, of course, more than one way to build a 'media ontology', for example: we might follow the semiotics of Cosgrove (1984) and Duncan (1990), the media archaeology of Kittler (1999; see also Crang 2015), trace the skein of relations of DeLanda and Latour (DeLanda 2006; Latour 2005; see also Anderson et al. 2012) or pursue a post-phenomenological interrogation of objects (Ash and Simpson 2014). I am not arguing there is a 'correct' theory here; I am arguing that to address popular culture it is necessary to think about mediation. All of the positions listed above, rigorously applied, offer opportunities for the investigation of the performance contemporary popular culture.

In answering this demand, I have argued elsewhere that we can understand 'the human' and technology as existing in a co-constitutive relation that can be called 'technicity' (Kinsley 2014; see also: Derrida and Stiegler 2002; Derrida 1997; Stiegler 1998). There isn't the one without the other. So, for example, rather than appeal to an amorphous alternate realm from which digital technologies draw their agency, we can instead study the particular spatial formations that reveal their ontogenetic bases (for more discussion of the ontogenetic nature of technicity, see Kinsley 2014; Kitchin and Dodge 2011). Returning to Jackson's (1989: 180) call to see 'opportunities' and not 'threats' in 'the contemporary intellectual terrain', we might therefore close with the 'opportunity' suggested through a conceptualisation of 'technicity'. To 'read', 'watch' and 'listen' to the particular qualities of phenomena we thus also need to understand the situatedness of those acts. Indeed, this resonates with (and, dare I say, extends) Jackson's own, later (see: Jackson 2000; 2010), call(s) for a re-materialisation of 
social and cultural geography (see also Anderson and Wylie 2009). In this way, 'culture' is an expression of 'technicity' (for more discussion, see Ash 2012b; Kinsley 2014), understood as the ways in which technologies (in their broadest sense) are an intimate and co-productive force in our experience of the world as 'humans'.

Cultural geographies are always and already 'sociotechnical' and geographies of popular culture are only ever more so. Thus I agree with Rose (2015) that we must attend to the 'interfaces' through which cultural production is performed, but likewise agree with Barnett (2015) that these are not peculiar to 'digital' cultural production. The 'popularity', 'ordinariness' and even 'vulgarity' of popular culture is contingent on the ways in which forms of cultural performance and production are 'read', 'watched', 'listened' to (and so on), and how they are distributed and shared, which intimately relies on technical mediation. Cultural geographers are, therefore, well placed to inform and enhance social scientific research concerning popular culture, in its broadest meaning, particularly in relation to the articulation of spatial experience and knowledge.

\section{References}

Anderson B, Kearnes MB, McFarlane C, et al. (2012) On assemblages and geography. Dialogues in Human Geography 2: 171-189.

Anderson B and Wylie J. (2009) On geography and materiality. Environment and Planning $A$ 41: 318-335.

Ash J. (2009) Emerging spatialities of the screen: video games and the reconfiguration of spatial awareness. Environment and Planning A 41: 2105-2124.

Ash J. (2012a) Attention, videogames and the retentional economies of affective amplification. Theory, Culture \& Society 29: 3-26.

Ash J. (2012b) Technology, Technicity and Emerging Practices of Temporal Sensitivity in Videogames. Environment and Planning A 44: 187-203.

Ash J and Simpson P. (2014) Geography and post-phenomenology. Progress in Human Geography.

Barnett C. (1998) The Cultural Turn: Fashion or progress in human geography. Antipode 30: 379-394.

Barnett C. (2008) A Critique of the Cultural Turn. In: Duncan J, Johnson NC and Schein RH (eds) A Companion to Cultural Geography. Oxford: Blackwell, 38-48.

Barnett C. (2015) Cultural Geography is Dead! Long Live Cultural Geography? Available at: https://clivebarnett.wordpress.com/2015/05/05/cultural-geographyis-dead-long-live-cultural-geography/.

Cosgrove D. (1984) Social Formation and Symbolic Landscape, London: Croom Helm.

Cosgrove D and Daniels S. (1988) The Iconography of Landscape, Cambridge: Cambridge University Press. 
Craine J. (2007) The medium has a new message: media and critical geography. ACME: An International E-Journal for Critical Geographies 6: 147-152.

Crang M. (2015) The promise and perils of a digital geohumanities. Cultural Geographies 22: 351-360.

DeLanda M. (2006) A new philosophy of society : assemblage theory and social complexity, London: Continuum.

Derrida J. (1997) Of Grammatology, Baltimore, MA: Johns Hopkins University Press.

Derrida J and Stiegler B. (2002) Echographies of Television: flimed interviews, Cambridge: Polity.

Duncan J. (1990) The City as Text: The politics of landscape interpretation in the Kandyan Kingdom, Cambridge: Cambridge University Press.

Duncan J and Duncan N. (1988) (Re)reading the landscape. Environment and Planning D: Society \& Space 6: 117-126.

Edensor T. (2002) National identity, popular culture and everyday life, Oxford: Berg.

Featherstone M. (1991) Consumer Culture and Postmodernism, London: Sage.

Fraser A. (2012) The Spaces, Politics, and Cultural Economies of Electronic Dance Music. Geography Compass 6: 500-511.

Jackson P. (1989) Maps of Meaning, Oxford: Routledge.

Jackson P. (2000) Re-materializing Social and Cultural Geography. Social \& Cultural Geography 1: 9-14.

Jackson P. (2010) Food stories: consumption in an age of anxiety. Cultural Geographies 17: 147-165.

Kinsley S. (2014) The matter of 'virtual' geographies. Progress in Human Geography 38: 364-384.

Kitchin R. (2014) Big data, new epistemologies and paradigm shifts. Big Data and Society 1: 1-12.

Kitchin R and Dodge M. (2011) Code/Space: Software and Everyday Life, Cambridge, MA: MIT Press.

Kittler F. (1999) Gramaphone, Film, Typewriter, Stanford, CA: Stanford University Press.

Latour B. (2005) Reassembling the social : an introduction to actor-network-theory, Oxford: Oxford University Press.

Longhurst R. (2009) YouTube: a new space of birth. Feminist Review 93: 46-63.

May J. (2010) Zombie geographies and the undead city. Social \& Cultural Geography 11: 285-298.

Miller D and Woodward S. (2012) Blue Jeans. The Art of the Ordinary, Berkeley, CA: University of California Press.

Ranciere J. (2011) Staging the people: The proletarian and his double, London: Verso.

Revill G. (2005) Vernacular culture and the place of folk music. Social \& Cultural Geography 6: 693-706.

Rose G. (2015) Rethinking the geographies of cultural 'objects' through digital technologies: Interface, network and friction. Progress in Human Geography In Press.

Simpson P. (2011) 'So, as you can see...': some reflections on the utility of video methodologies in the study of embodied practices. Area 43: 343-352.

Stedman Jones G. (1983) Languages of Class, Cambridge: Cambridge University Press.

Stiegler B. (1998) Technics and Time, 1: The Fault of Epimetheus, Stanford, CA: Stanford University Press. 